[Research Note]

\title{
Catalytic Activities of Platinum Supported on Silica-modified Alumina for Hydrodesulfurization of Thiophene
}

\author{
Yasuharu KANDA*, Yasunobu OoKa, Takao KobaYASHI, Yoshio UEMichi, and Masatoshi SugioKa \\ Dept. of Applied Chemistry, Muroran Institute of Technology, 27-1 Mizumoto-cho, Muroran, Hokkaido 050-8585, JAPAN \\ (Received May 17, 2006)
}

\begin{abstract}
Hydrodesulfurization (HDS) of thiophene over silica-modified alumina-supported platinum ( $\left.\mathrm{Pt} / \mathrm{SiO}_{2}-\mathrm{Al}_{2} \mathrm{O}_{3}\right)$ catalysts was examined. The HDS activity of a $\mathrm{Pt} / \mathrm{Al}_{2} \mathrm{O}_{3}$ catalyst was enhanced by silica modification. However, the optimal silica loading for HDS activity could not be identified. The dispersion of platinum on alumina, as measured by the hydrogen adsorption method, was enhanced by silica modification and the optimal silica loading for platinum dispersion was 10 to $40 \mathrm{wt} \%$. The acidity of $\mathrm{SiO}_{2}-\mathrm{Al}_{2} \mathrm{O}_{3}$ was evaluated by 2-propanol dehydration $\left(200^{\circ} \mathrm{C}\right)$ and cumene cracking $\left(400^{\circ} \mathrm{C}\right)$. The optimal silica loading for the acidity of $\mathrm{SiO}_{2}-\mathrm{Al}_{2} \mathrm{O}_{3}$ was $90 \mathrm{wt} \%$. Furthermore, the presence of Brönsted acid sites on $\mathrm{SiO}_{2}-\mathrm{Al}_{2} \mathrm{O}_{3}$ was confirmed by a pyridine adsorption method with FT-IR spectroscopy. The high HDS activity of the $\mathrm{Pt} / \mathrm{SiO}_{2}-\mathrm{Al}_{2} \mathrm{O}_{3}$ catalyst is caused by both high Pt dispersion and formation of Brönsted acid sites.
\end{abstract}

\section{Keywords}

Hydrodesulfurization, Thiophene, Platinum catalyst, Silica modification, Bifunctional catalysis

\section{Introduction}

Hydrodesulfurization (HDS) of petroleum feedstocks is one of the important processes in the petroleum industry to produce clean fuels ${ }^{1) \sim 4)}$. Highly active HDS catalysts, which exhibit higher activity than commercial $\mathrm{CoMo} / \mathrm{Al}_{2} \mathrm{O}_{3}$ HDS catalyst, have been developed to produce lower sulfur content fuels ${ }^{5), 6)}$.

We previously investigated the development of highly active supported noble metal HDS catalysts ${ }^{7)^{\sim 15}}$. Supported noble metal catalysts, especially platinum supported on zeolites ${ }^{7,8), 12)}$ and mesoporous silicates ${ }^{9) \sim 12)}$, had higher HDS activities than commercial CoMo/ $\mathrm{Al}_{2} \mathrm{O}_{3}$ HDS catalyst. We also reported that the HDS activities of Pt supported on silica gel $\left(\mathrm{SiO}_{2}\right)^{13)}$ and mesoporous silica MCM-414),15) were enhanced by alumina modification of the siliceous support. We concluded that the high activities of these catalysts were caused by the formation of both highly dispersed Pt particles and Brönsted acid sites on the supported $\mathrm{Pt}$ catalyst, which act as the active sites for the HDS of thiophene. Therefore, we expected that the HDS activity of $\mathrm{Pt} / \mathrm{Al}_{2} \mathrm{O}_{3}$ could also be enhanced by the modification of alumina with silica.

In the present study, we examined the catalytic performance of platinum supported on silica-modified alu-

\footnotetext{
* To whom correspondence should be addressed.

* E-mail: kanda@mmm.muroran-it.ac.jp
}

mina $\left(\mathrm{SiO}_{2}-\mathrm{Al}_{2} \mathrm{O}_{3}\right)$ for the HDS of thiophene. The catalytic properties of $\mathrm{Pt} / \mathrm{SiO}_{2}-\mathrm{Al}_{2} \mathrm{O}_{3}$ were characterized to clarify the essential factors involved in the HDS activity of supported Pt catalyst.

\section{Experimental}

Alumina $\left(\mathrm{Al}_{2} \mathrm{O}_{3}\right.$, JRC-ALO-8) was obtained from the Catalysis Society of Japan, and silica $\left(\mathrm{SiO}_{2}\right)$ from Nippon Aerosil Co. Silica-modified alumina $\left(\mathrm{SiO}_{2}-\mathrm{Al}_{2} \mathrm{O}_{3}\right)$ was prepared by an impregnation method using tetraethoxysilane (TEOS, $\mathrm{Si}\left(\mathrm{OC}_{2} \mathrm{H}_{5}\right)_{4}$, Kanto Chemical Co.) ethanol solution. After TEOS impregnation, supports were dried at $120^{\circ} \mathrm{C}$ and then calcined at $500^{\circ} \mathrm{C}\left(10^{\circ} \mathrm{C} / \mathrm{min}\right)$ for $4 \mathrm{~h}$ in air. Supported Pt catalysts were prepared by an impregnation method using hydrogen hexachloroplatinate $\left(\mathrm{H}_{2} \mathrm{PtCl}_{6} \cdot 6 \mathrm{H}_{2} \mathrm{O}\right.$, Kanto Chemical Co.) aqueous solution and the Pt loading was $5 \mathrm{wt} \%$. All catalysts were dried at $120^{\circ} \mathrm{C}$ and then calcined at $500^{\circ} \mathrm{C}\left(10^{\circ} \mathrm{C} / \mathrm{min}\right)$ for $4 \mathrm{~h}$ in air. The catalysts were pretreated with helium at $500^{\circ} \mathrm{C}$ for $1 \mathrm{~h}$ and then reduced with hydrogen at $450^{\circ} \mathrm{C}$ for $1 \mathrm{~h}$ prior to the reaction. HDS of thiophene was carried out at $350^{\circ} \mathrm{C}$ under $0.1 \mathrm{MPa}$ using a conventional fixed bed flow reactor. Thiophene was introduced into the reactor by passing the hydrogen stream $(30 \mathrm{ml} / \mathrm{min})$ through a saturator containing liquid thiophene at $0^{\circ} \mathrm{C}$. Reaction conditions were as follows: catalyst weight $=0.1 \mathrm{~g}$, $\mathrm{H}_{2} /$ thiophene $=30 \mathrm{~mol} / \mathrm{mol}, W / F=37.9 \mathrm{~g} \cdot \mathrm{h} / \mathrm{mol}$. The 


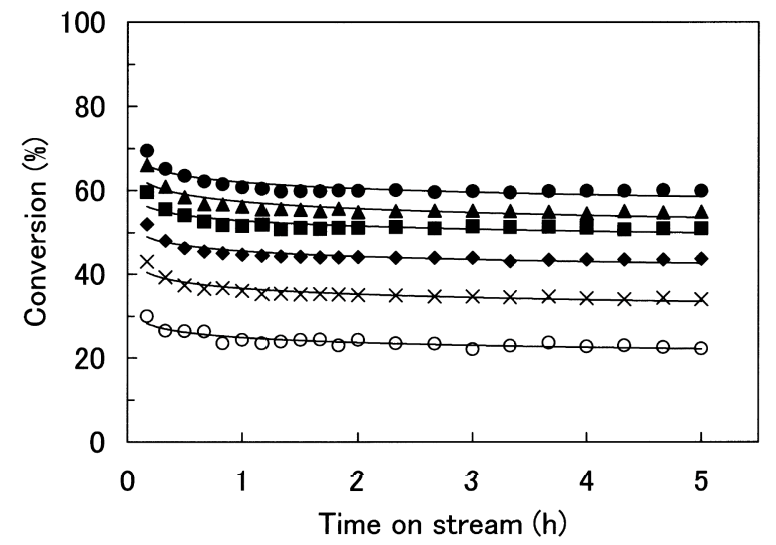

$\mathrm{H}_{2} /$ thiophene $=30, \mathrm{~W} / \mathrm{F}=37.9 \mathrm{~g} \cdot \mathrm{h} / \mathrm{mol}$

$\mathrm{Al}_{2} \mathrm{O}_{3}, \times 2.5 \mathrm{wt} \% \mathrm{SiO}_{2}-\mathrm{Al}_{2} \mathrm{O}_{3}, 4.9 \mathrm{wt} \% \mathrm{SiO}_{2}-\mathrm{Al}_{2} \mathrm{O}_{3}$ $11 \mathrm{wt} \% \mathrm{SiO}_{2}-\mathrm{Al}_{2} \mathrm{O}_{3}, \boldsymbol{\Delta} 28 \mathrm{wt} \% \mathrm{SiO}_{2}-\mathrm{Al}_{2} \mathrm{O}_{3}, 00 \mathrm{wt} \%$ $\mathrm{SiO}_{2}-\mathrm{Al}_{2} \mathrm{O}_{3}$.

Fig. 1 Hydrodesulfurization of Thiophene over $\mathrm{Pt} / \mathrm{SiO}_{2}-\mathrm{Al}_{2} \mathrm{O}_{3}$ Catalysts at $350^{\circ} \mathrm{C}$

reaction products were analyzed by gas chromatography (FID) with silicone DC-550 $\left(2 \mathrm{~m}, 150^{\circ} \mathrm{C}\right)$ and VZ-7 $\left(4 \mathrm{~m}, 0^{\circ} \mathrm{C}\right)$ columns, respectively.

The dispersion of platinum on $\mathrm{SiO}_{2}-\mathrm{Al}_{2} \mathrm{O}_{3}$ was measured by hydrogen adsorption. Adsorption of hydrogen on the supported Pt catalyst was carried out in a Pyrex glass vacuum system at $25^{\circ} \mathrm{C}$. The supported Pt catalysts were stood under a vacuum at $500^{\circ} \mathrm{C}$ for $1 \mathrm{~h}$ followed by reduction with hydrogen $(26.7 \mathrm{kPa})$ at $450^{\circ} \mathrm{C}$ for $1 \mathrm{~h}$ and stood under a vacuum at the same temperature for $1 \mathrm{~h}$ before hydrogen adsorption. The acidity of $\mathrm{SiO}_{2}-\mathrm{Al}_{2} \mathrm{O}_{3}$ was evaluated by 2-propanol (2-PA) dehydration $\left(200^{\circ} \mathrm{C}\right)$ and cumene cracking $\left(400^{\circ} \mathrm{C}\right)$ using a pulse reactor with helium carrier gas. For both reactions, the catalyst $(0.03 \mathrm{~g})$ was charged into the reactor and pretreated at $500^{\circ} \mathrm{C}$ for $1 \mathrm{~h}$ before the reaction. Fourier transform infrared spectroscopy (FT-IR) spectra of pyridine adsorbed on $\mathrm{Al}_{2} \mathrm{O}_{3}$ and $\mathrm{SiO}_{2}-\mathrm{Al}_{2} \mathrm{O}_{3}$ were observed using a Jasco FT-IR spectrometer. The catalysts were stood under a vacuum at $500^{\circ} \mathrm{C}$ for $2 \mathrm{~h}$ prior to the measurement.

\section{Results and Discussion}

The effect of silica modification on the catalytic activity of Pt supported on $\mathrm{Al}_{2} \mathrm{O}_{3}$ for the HDS of thiophene was examined at $350^{\circ} \mathrm{C}$. The catalytic activity of $\mathrm{Pt} / \mathrm{Al}_{2} \mathrm{O}_{3}$ was enhanced by silica modification of $\mathrm{Al}_{2} \mathrm{O}_{3}$ as shown in Fig. 1. Figure 2 shows the relationship between the amount of $\mathrm{SiO}_{2}$ loading and HDS activity of $\mathrm{Pt} / \mathrm{SiO}_{2}-\mathrm{Al}_{2} \mathrm{O}_{3}$ after reaction for $2 \mathrm{~h}$. The HDS activities of $\mathrm{Pt} / \mathrm{SiO}_{2}-\mathrm{Al}_{2} \mathrm{O}_{3}$ catalysts were higher than those of $\mathrm{Pt} / \mathrm{Al}_{2} \mathrm{O}_{3}$ and $\mathrm{Pt} / \mathrm{SiO}_{2}$ catalysts. The optimal $\mathrm{SiO}_{2}$ loading for the HDS activity of $\mathrm{Pt} /$

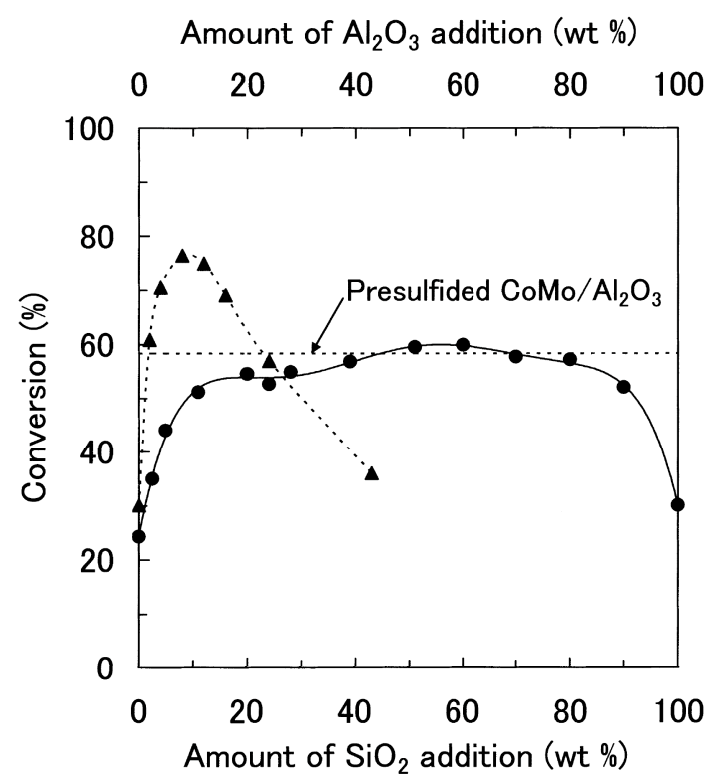

Effect of $\mathrm{SiO}_{2}$ modification on HDS activity of $\mathrm{Pt} / \mathrm{SiO}_{2}-\mathrm{Al}_{2} \mathrm{O}_{3}$, $\Delta$ Effect of $\mathrm{Al}_{2} \mathrm{O}_{3}$ modification on HDS activity of $\mathrm{Pt} / \mathrm{Al}_{2} \mathrm{O}_{3}-\mathrm{SiO}_{2}$ catalyst $^{13)}$.

Fig. 2 Effect of Surface Modification on the HDS Activities of Pt/ $\mathrm{SiO}_{2}-\mathrm{Al}_{2} \mathrm{O}_{3}$ and $\mathrm{Pt} / \mathrm{Al}_{2} \mathrm{O}_{3}-\mathrm{SiO}_{2}$ Catalysts

$\mathrm{SiO}_{2}-\mathrm{Al}_{2} \mathrm{O}_{3}$ could not be identified. However, the enhanced activities of $\mathrm{Pt} / \mathrm{SiO}_{2}-\mathrm{Al}_{2} \mathrm{O}_{3}$ catalysts in the range of $\mathrm{SiO}_{2}$ loading from 10 to $90 \mathrm{wt} \%$ were comparable to that of sulfided commercial $\mathrm{CoMo} / \mathrm{Al}_{2} \mathrm{O}_{3}$ catalyst. The relationship between the amount of $\mathrm{Al}_{2} \mathrm{O}_{3}$ loading and HDS activity of Pt supported on alumina-modified $\mathrm{SiO}_{2}\left(\mathrm{Al}_{2} \mathrm{O}_{3}-\mathrm{SiO}_{2}\right)$ after reaction for $2 \mathrm{~h}^{13)}$ is presented in Fig. 2. The optimal $\mathrm{Al}_{2} \mathrm{O}_{3}$ loading for the HDS activity of $\mathrm{Pt} / \mathrm{Al}_{2} \mathrm{O}_{3}-\mathrm{SiO}_{2}$ was clearly observed as $8 \mathrm{wt} \%$. The effect of silica modification on catalytic activity of $\mathrm{Pt} / \mathrm{Al}_{2} \mathrm{O}_{3}$ was remarkably different from the effect of alumina modification on catalytic activity of $\mathrm{Pt} / \mathrm{SiO}_{2}$. We previously reported that the dispersion of $\mathrm{Pt}$ on $\mathrm{SiO}_{2}$ was enhanced to about 0.8 with $\mathrm{Al}_{2} \mathrm{O}_{3}$ loading from 8 to $24 \mathrm{wt} \%{ }^{13)}$. Therefore, we performed detailed characterizations of $\mathrm{Pt} / \mathrm{SiO}_{2}-\mathrm{Al}_{2} \mathrm{O}_{3}$ catalysts to clarify why the optimal amount of $\mathrm{SiO}_{2}$ loading for the HDS of thiophene was not observed.

Dispersion of $\mathrm{Pt}$ on $\mathrm{Al}_{2} \mathrm{O}_{3}$ and $\mathrm{SiO}_{2}-\mathrm{Al}_{2} \mathrm{O}_{3}$ was measured by the hydrogen adsorption method. Figure 3 shows the effect of silica modification of $\mathrm{Al}_{2} \mathrm{O}_{3}$ on the dispersion of $\mathrm{Pt}$ in $\mathrm{Pt} / \mathrm{SiO}_{2}-\mathrm{Al}_{2} \mathrm{O}_{3}$ catalysts. The dispersion of $\mathrm{Pt}$ on $\mathrm{Al}_{2} \mathrm{O}_{3}$ was higher than that on $\mathrm{SiO}_{2}$. The Pt precursor such as $\left[\mathrm{PtCl}_{6}\right]^{2-}$ reacts with the hydroxyl groups on the $\mathrm{Al}_{2} \mathrm{O}_{3}$ surface $(\mathrm{Al}-\mathrm{OH})^{16), 17)}$. Furthermore, $\left[\mathrm{PtCl}_{6}\right]^{2-}$ is adsorbed irreversibly on the $\mathrm{Al}_{2} \mathrm{O}_{3}$ surface by drying at $90^{\circ} \mathrm{C}^{17}$. In contrast, the hydroxyl group on the $\mathrm{SiO}_{2}$ surface $\left(\mathrm{Si}^{-} \mathrm{OH}\right)$ also acts as a ligand of the $\mathrm{Pt}$ complex, but the $\mathrm{Si}^{-} \mathrm{OH}$ ligand in the Pt complex is reversibly exchanged with $\mathrm{H}_{2} \mathrm{O}$ even 


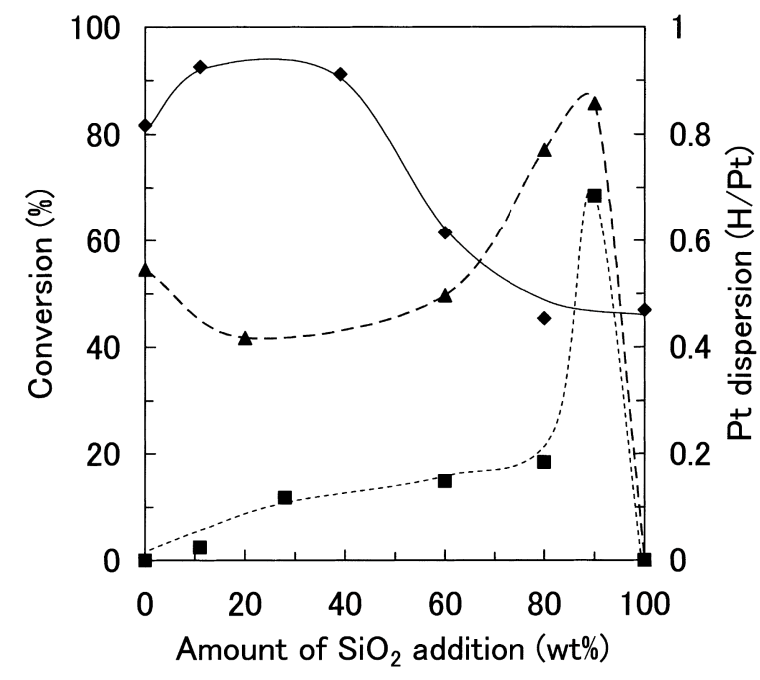

Dispersion of Pt, $\boldsymbol{\Delta}$ 2-propanol dehydration, $\mathbf{D}$ Cumene cracking.

Fig. 3 Effect of $\mathrm{SiO}_{2}$ Modification of $\mathrm{Al}_{2} \mathrm{O}_{3}$ Support on the Dispersion of $\mathrm{Pt}$ on $\mathrm{SiO}_{2}-\mathrm{Al}_{2} \mathrm{O}_{3}$ and Catalytic Activities of $\mathrm{SiO}_{2}-\mathrm{Al}_{2} \mathrm{O}_{3}$ for Acid-catalyzed Reactions

after drying at $90^{\circ} \mathrm{C}^{18)}$. These results indicate that the interaction between $\mathrm{Pt}$ particles and the $\mathrm{Al}_{2} \mathrm{O}_{3}$ surface is stronger than that with the $\mathrm{SiO}_{2}$ surface. Thus, the dispersion of $\mathrm{Pt}$ in $\mathrm{Pt} / \mathrm{Al}_{2} \mathrm{O}_{3}$ was higher than that in $\mathrm{Pt} /$ $\mathrm{SiO}_{2}$. However, the dispersion of $\mathrm{Pt}$ in $\mathrm{Pt} / \mathrm{Al}_{2} \mathrm{O}_{3}$ was enhanced by silica modification as discussed below.

The acidic properties of supports can be evaluated by measuring the dehydration of 2-propanol (2-PA), which proceeds on both Lewis and Brönsted acid sites, and the cracking of cumene, which proceeds only on Brönsted acid sites. The acidic properties of $\mathrm{Al}_{2} \mathrm{O}_{3}$ and $\mathrm{SiO}_{2}-\mathrm{Al}_{2} \mathrm{O}_{3}$ were evaluated with 2-PA dehydration (200 ${ }^{\circ} \mathrm{C}$ ) and cumene cracking $\left(400^{\circ} \mathrm{C}\right)$ using a pulse reactor. The 2-PA dehydration activity decreased, whereas the cumene cracking activity increased with increasing $\mathrm{SiO}_{2}$ loading. These results are also shown in Fig. 3, indicating that the Lewis acid sites on $\mathrm{Al}_{2} \mathrm{O}_{3}$ were covered by $\mathrm{SiO}_{2}$ addition, resulting in formation of Brönsted acid sites. The highest activities for both acidcatalyzed reactions were found in $90 \mathrm{wt} \% \mathrm{SiO}_{2}-\mathrm{Al}_{2} \mathrm{O}_{3}$. Furthermore, the presence of Brönsted acid sites on $\mathrm{SiO}_{2}-\mathrm{Al}_{2} \mathrm{O}_{3}$ was confirmed by the FT-IR spectra of pyridine adsorbed on $\mathrm{SiO}_{2}-\mathrm{Al}_{2} \mathrm{O}_{3}$ (at $1547 \mathrm{~cm}^{-1}$ ) as shown in Fig. 4. The dispersion of Pt on ZSM-5 zeolite increases with increasing proton content ${ }^{8)}$. The anionic $\mathrm{Pt}$ precursor such as $\left[\mathrm{PtCl}_{6}\right]^{2-}$ interacts electrostatically with the Brönsted acid sites on the $\mathrm{SiO}_{2}-\mathrm{Al}_{2} \mathrm{O}_{3}$ surface. Therefore, the dispersion of $\mathrm{Pt}$ on $\mathrm{SiO}_{2}-\mathrm{Al}_{2} \mathrm{O}_{3}$ was slightly enhanced by increasing the $\mathrm{SiO}_{2}$ loading from 10 to $40 \mathrm{wt} \%$.

Previously, we proposed two reaction routes for HDS of thiophene over highly active $\mathrm{Pt} / \mathrm{Al}_{2} \mathrm{O}_{3}-\mathrm{SiO}_{2}$ catalyst: (i) a monofunctional route in which HDS reactions pro-

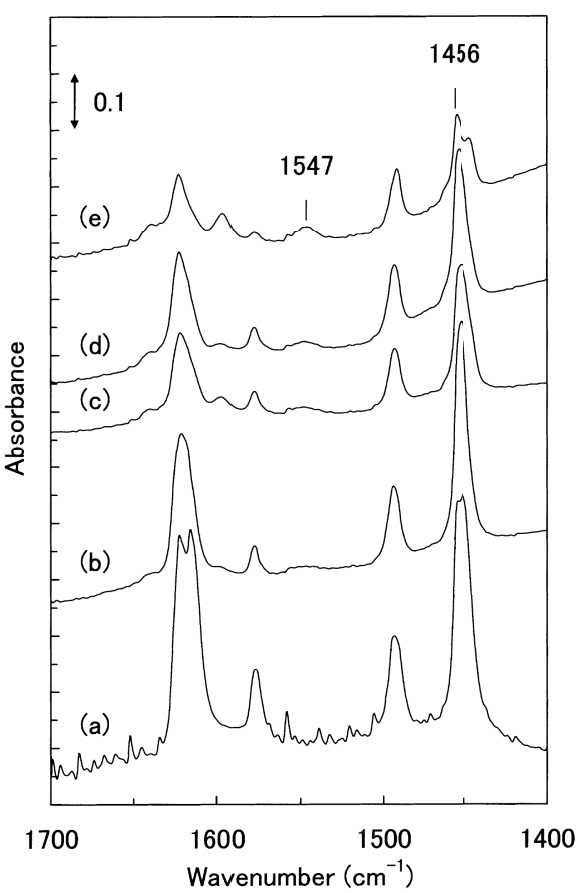

Pyridine was adsorbed at $150^{\circ} \mathrm{C}$ followed by standing in a vacuum at $150^{\circ} \mathrm{C}$ for $0.5 \mathrm{~h}$.

Fig. 4 FT-IR Spectra of Pyridine Adsorbed on (a) $\mathrm{Al}_{2} \mathrm{O}_{3}$, (b) $11 \mathrm{wt} \% \mathrm{SiO}_{2}-\mathrm{Al}_{2} \mathrm{O}_{3}$, (c) $39 \mathrm{wt} \% \mathrm{SiO}_{2}-\mathrm{Al}_{2} \mathrm{O}_{3}$, (d) $60 \mathrm{wt} \%$ $\mathrm{SiO}_{2}-\mathrm{Al}_{2} \mathrm{O}_{3}$ and (e) $90 \mathrm{wt} \% \mathrm{SiO}_{2}-\mathrm{Al}_{2} \mathrm{O}_{3}$

ceed only on Pt particles, and (ii) a bifunctional route in which both Pt particles and Brönsted acid sites are involved in the HDS reaction ${ }^{13)}$. In reaction route (ii), thiophene is activated on the Brönsted acid sites of $\mathrm{Al}_{2} \mathrm{O}_{3}-\mathrm{SiO}_{2}$ and hydrogen is activated on the Pt particles to form spillover hydrogen. In the present study, we observed that the Brönsted acid sites were generated by silica modification of $\mathrm{Al}_{2} \mathrm{O}_{3}$ as shown in Figs. $\mathbf{3}$ and 4. Therefore, both the Pt particles and Brönsted acid sites in the $\mathrm{Pt} / \mathrm{SiO}_{2}-\mathrm{Al}_{2} \mathrm{O}_{3}$ catalyst can act as active sites in the HDS of thiophene, as in the $\mathrm{Pt} / \mathrm{Al}_{2} \mathrm{O}_{3}-\mathrm{SiO}_{2}$ catalyst. However, Pt dispersion and Brönsted acidity were low but $\mathrm{HDS}$ activity of $\mathrm{Pt} / \mathrm{SiO}_{2}-\mathrm{Al}_{2} \mathrm{O}_{3}$ catalyst was not low in the range of $\mathrm{SiO}_{2}$ loading from 60 to $80 \mathrm{wt} \%$. Previously, we reported that the high activity of Pt/alumina-modified MCM-41 catalyst for HDS reaction is due to the good balance of high dispersion of Pt particles and Brönsted acidity of the support ${ }^{15)}$. This indicates that both high Pt dispersion and Brönsted acidity of the support are important in the preparation of highly active supported Pt HDS catalyst.

\section{Conclusions}

The optimal $\mathrm{SiO}_{2}$ loading for the activity of $\mathrm{Pt} /$ $\mathrm{SiO}_{2}-\mathrm{Al}_{2} \mathrm{O}_{3}$ in $\mathrm{HDS}$ reaction could not be identified, in contrast to $\mathrm{Pt} / \mathrm{Al}_{2} \mathrm{O}_{3}-\mathrm{SiO}_{2}$. The characterization re- 
sults of the catalysts revealed that the optimal $\mathrm{SiO}_{2}$ loading for dispersion of $\mathrm{Pt}$ on $\mathrm{SiO}_{2}-\mathrm{Al}_{2} \mathrm{O}_{3}$ was 10 to $40 \mathrm{wt} \%$, and that for Brönsted acidity was $c a .90 \mathrm{wt} \%$. We conclude that the high HDS activity of the Pt/ $\mathrm{SiO}_{2}-\mathrm{Al}_{2} \mathrm{O}_{3}$ catalyst results from both high Pt dispersion and formation of Brönsted acid sites.

\section{Acknowledgment}

We would like to thank Nippon Aerosil Co., for supplying the silica gel.

\section{References}

1) Prins, R., de Beer, V. H. J., Somorjai, G. A., Catal. Rev.-Sci. Eng., 31, 1 (1989).

2) Chianelli, R. R., Daage, M., Ledoux, M. J., Adv. Catal., 40, 177 (1994).

3) Topsøe, H., Clausen, B. S., Massoth, F. E., Catal.-Sci. Tech., 11, 1 (1996).

4) Whitehurst, D. D., Isoda, T., Mochida, I., Adv. Catal., 4, 345 (1998).

5) Sugioka, M., PETROTECH, 19, (6), 458 (1996).

6) Kabe, T., Ishihara, A., Qian, W., "Hydrodesulfurization and
Hydrodenitrogenation," Kodansha Scientific, Wiley-VCH, Tokyo, New York, Berlin (1999), p. 266.

7) Sugioka, M., Sado, F., Kurosaka, T., Wang, X., Catal. Today, 45, 327 (1998).

8) Kurosaka, T., Sugioka, M., Matsuhashi, H., Bull. Chem. Soc. Jpn., 74, 757 (2001).

9) Sugioka, M., Andalaluna, L., Morishita, S., Kurosaka, T., Catal. Today, 39, 61 (1997).

10) Sugioka, M., Morishita, S., Kurosaka, T., Seino, A., Nakagawa, M., Namba, S., Stud. Surf. Sci. Catal., 125, 531 (1999).

11) Sugioka, M., Aizawa, T., Kanda, Y., Kurosaka, T., Uemichi, Y., Namba, S., Stud. Surf. Sci. Catal., 142, 739 (2002).

12) Sugioka, M., Kurosaka, T., J. Jpn. Petrol. Inst., 45, (6), 342 (2002).

13) Kanda, Y., Kobayashi, T., Uemichi, Y., Sugioka, M., J. Jpn. Petrol. Inst., 49, (2), 49 (2006).

14) Kanda, Y., Uemichi, Y., Kobayashi, T., Andalaluna, L., Sugioka, M., Stud. Surf. Sci. Catal., 156, 747 (2005).

15) Kanda, Y., Kobayashi, T., Uemichi, Y., Namba, S., Sugioka, M., Appl. Catal. A: General, 308, 111 (2006).

16) Martens, J. H. A., Prins, R., Appl. Catal., 46, 31 (1989).

17) Shelimov, B., Lambert, J. F., Che, M., Didillon, B., J. Catal., 185, 462 (1999).

18) Boujday, S., Lehman, J., Lambert, J. F., Che, M., Catal. Lett., 88, 23 (2003).

\section{要旨}

\section{チオフェンの水素化脱硫反応に対するシリカ修飾アルミナ担持白金の触媒活性}

神田 康晴, 大岡 康伸, 小林 隆夫, 上道 芳夫, 杉岡 正敏

室蘭工業大学応用化学科, 050-8585 北海道室蘭市水元町27-1

\footnotetext{
シリカ修飾アルミナ担持白金 $\left(\mathrm{Pt} / \mathrm{SiO}_{2}-\mathrm{Al}_{2} \mathrm{O}_{3}\right)$ のチオフェン の水素化脱硫（HDS）活性および特性について検討した。アル ミナ担持白金 $\left(\mathrm{Pt} / \mathrm{Al}_{2} \mathrm{O}_{3}\right)$ の HDS 活性はシリカ修飾を施すこと によって向上するが, $\mathrm{Pt} / \mathrm{SiO}_{2}-\mathrm{Al}_{2} \mathrm{O}_{3}$ の $\mathrm{HDS}$ 活性に対する最適 シリカ添加量は確認されなかった。 $\mathrm{Pt} / \mathrm{SiO}_{2}-\mathrm{Al}_{2} \mathrm{O}_{3}$ における白金 の分散度は水素吸着法によって測定した。その結果, 白金の分 散度はアルミナにシリカ修飾を施すことによって向上し，白金 の分散度に対するシリカの最適添加量は 10 から $40 \mathrm{wt} \%$ である
}

\begin{abstract}
ことを明らかにした。 $\mathrm{SiO}_{2}-\mathrm{Al}_{2} \mathrm{O}_{3}$ の酸性質は2-プロパノールの 脱水反応 $\left(200^{\circ} \mathrm{C}\right)$ 抢よびクメンの分解反応 $\left(400^{\circ} \mathrm{C}\right)$ より評価 した。これより， $\mathrm{SiO}_{2}-\mathrm{Al}_{2} \mathrm{O}_{3}$ の酸性質に対する最適シリカ添加 量は $90 \mathrm{wt} \%$ であることを明らかにした。さらに, 吸着ピリジ ン FT-IR スペクトルょり $\mathrm{SiO}_{2}-\mathrm{Al}_{2} \mathrm{O}_{3}$ には Brönsted 酸点が存在 することを確認した。以上の結果から, $\mathrm{Pt} / \mathrm{Al}_{2} \mathrm{O}_{3}$ 触媒の HDS 活性がシリカ修飾により向上したのは, Pt の分散度㧍よび担 体の Brönsted 酸性が高められたためであると結論した。
\end{abstract}

